\title{
MENGEMBANGKAN KEMAMPUAN KREATIVITAS MEWARNAI PADA PESERTA DIDIK USIA DINI DENGAN KEGIATAN FINGER PAINTING
}

\author{
Ahmad Fachrurrazi \\ Universitas PGRI Adi Buana Surabaya \\ amangrozy@gmail.com \\ Ana Setyaningsih \\ Universitas PGRI Adi Buana Surabaya \\ anasetyaa1@gmail.com
}

\begin{abstract}
This research was motivated by children using Finger Painting activities to introduce the concept of mixing colors children can develop creativity. This study was used to determine Finger Painting activities on the creativity abilities of the participants in group B of Al-Hikmah Kindergarten Surabaya. Finger Painting activities are suitable for improving children's creativity, because there are aspects of creativity that appear in Finger Painting activities that provide an opportunity for children to imagine in determining any image that their children will get a picture idea or color idea. This research was conducted in in group B TK Al-Hikmah Surabaya. The sample technique used in this study is Nonprobability sampling with a form of saturated sampling. The data collected by instruments of performance observation sheet. and analyzed with a one-group pre-test post-test design. Based on the results of data analysis which shows that the value of $t$-count $=4.20$ is greater than $t$-table 1.734 with a significance level of 0.05 and 2.552 at the 0.01 significance level with $N=19$ which means the null hypothesis (Ho) is rejected and the working hypothesis $(\mathrm{Hl})$ is accepted. It can be concluded that Finger Painting activities can influence to the children's coloring creativity.
\end{abstract}

Keywords: Finger Painting Activities, Coloring Creativity.

\section{PENDAHULUAN}

Perkembangan fisik merupakan hal yang menjadi dasar bagi kemajuan perkembangan berikutnya. Ketika fisik berkembang dengan baik memungkinkan anak untuk dapat lebih mengembangkan keterampilan fisiknya dan mengeksplorasi lingkungannya dengan tanpa bantuan dari orang lain. Perkembangan fisik anak ditandai juga dengan berkembangnya perkembangan motorik, baik motorik halus maupun motorik kasar.
Perkembangan fisik adalah pertumbuhan dan perubahan yang terjadi pada tubuh atau badan atau jasmani seseorang. Perkembangan fisik manusia terjadi mengikuti prinsip cephalocaudal, yaitu bahwa kepala dan bagian atas tubuh berkembang lebih dahulu sehingga bagian atas tampak lebih besar daripada bawah.

Perkembangan motorik (motoric development) adalah perubahan secara progresif pada kontrol dan kemampuan untuk melakukan gerakan yang 
diperoleh melalui interaksi antara faktor kematangan (maturation) dan latihan/pengalaman (experiences) selama kehidupan yang dapat dilihat melalui perubahan/gerakan yang dilakukan.

Menurut Papalia, Olds, \& Feldman (dalam Hildayani,dkk 2008:8.13) Anak usia 4-6 tahun berada pada tahap perkembangan early childhood masa kanak-kanak awal yang secara teori dimulai dari usia 3 tahun. Tahap usia ini biasa disebut sebagai periode prasekolah.

Santrock (dalam Sujiono dan Sujiono 2010:38) menyatakan bahwa kreativitas adalah kemampuan untuk memikirkan sesuatu dengan cara-cara yang baru dan tidak biasa serta melahirkan suatu solusi yang unik terhadap masalah-masalah yang dihadapi.

Selanjutnya Gallagher (dalam Sujiono dan Sujiono, 2010:38) menyatakan bahwa kreativitas berhubungan dengan kemampuan untuk menciptakan sesuatu yang baru, yang belum ada sebelumnya.

Sementara menurut Mayesty (dalam Sujiono dan Sujiono 2010:39) anak-anak secara alamiah pada dasarnya kreatif, ini berarti bahwa apa yang mereka lakukan adalah unik dan berguna bagi diri mereka sendiri bahkan juga berguna bagi orang lain.

Hubungan kreativitas dan aktualisasi diri, Maslow (dalam Sujiono dan Sujiono 2010:40) menyatan orang yang mampu mengaktualisasikan diri adalah orang yang kreatif, orang yang sangat peduli terhadap proses daripada klimaks keberhasilan dan kebanggaan terhadap sukses tersebut.

Utami Munandar (dalam Asrori 2015: 63) menyatakan kreativitas adalah kemampuan yang mencerminkan kelancaran, keluwesan, dan orisinalitas dalam berpikir serta kemampuan untuk mengelaborasi suatu gagasan. kreativitas sebagai keseluruhan kepribadian merupakan hasil interaksi dengan lingkungannya.

Pada usia 4-6 tahun biasanya kemampuan mewarnai anak semakin baik. Coretan waranya mulai teratur, anak juga sudah mulai dapat memenuhi bidang gambar yang diwarnainya. Walaupun sering kali pada satu bidang gambar dapat diberi lebih dari satu warna walaupun goresannya tidak selalu terlihat rapi searah, namun tampak sudah ada usahanya dalam menjaga agar coretan tidak keluar dari garis gambar/bidang yang harus diwarnainya. Kemampuan untuk mewarnai gambar dengan rapi, tidak mencoret warna hingga keluar bidang gambar, baru akan diperoleh anak mendekati usia 5 tahun.

Hal yang perlu diperhatikan adalah kemampuan anak dalam mewarnai. Jika ia enggan menyelesaikan pekerjaan mewarnai gambarnya, cobalah melatih kesabarannya dalam menyelesaikan satu pekerjaan hingga 
tuntas, sebelum beralih pada pekerjaan yang lain. Bagi beberapa anak, pekerjaan mewarnai gambar memang bukan pekerjaan yang menyenangkan. Apalagi jika hasilnya kemudian dibandingkan dengan hasil pewarnaan gambar milik temannya yang lebih sempurna.

Aktivitas menggambar atau mewarnai merupakan aktualisasi diri anak dalam bidang seni. Dengan menggambar atau mewarnai, imajinasi anak akan tumbuh dan berkembang sejalan dengan proses kreativitas yang semakin berkembang. Pada saat anak mencoret-coret di kertas tidak dapat dipungkiri bahwa dia akan menggunakan imajinasi yang dituangkan dalam bentuk hasil karya. Imajinasi identik dengan kreativitas, dan kreativitas berkaitan erat dengan peran dan fungsi otak kanan.

Mewarnai biasanya diberikan kepada anak-anak tingkat TK, dimana mereka mulai mengenal aneka warna dan menggoreskan sesuatu pada sebidang kertas. Dalam mewarnai gambar, anak TK dapat melakukan dengan baik, tentunya melalui bimbingan tersendiri di sekolahnya melalui teknik-teknik mewarnai yang tepat sesuai dengan kemampuan anak. Belajar mewarnai akan membuat anak senang berekplorasi dengan warna.

Berdasarkan konsep-konsep yang dikemukakan oleh para pakar tersebut dapat dipahami bahwa pengembangan kreativitas pada anak usia dini memang sangat diperlukan. Lebih-lebih pada anak usia dini terdapat masa emas perkembangan yang bisa mempengaruhi perkembangan mereka pada masa-masa selanjutnya.

Atas dasar hasil observasi awal yang dilakukan pada pra penelitian teridentifikasi permasalahan yang ditemukan oleh peneliti pada kelompok B TK AL-HIKMAH kemampuan peserta didik dalam hal kreativitas mewarnai masih masih dalam tingkat capaian perkembangan mulai berkembang. Pada kelompok B TK AL-HIKMAH yang berjumlah 19 peserta didik, 3 peserta didik masih kurang dalam mengenal konsep warna, 8 peserta didik masih kurang mampu dalam mengenal konsep pencampuran warna. Hal itu disebabkan karena kegiatan/pembelajaran yang dilakukan oleh guru kurang maksimal dalam media pembelajaran pengenalan warna. Hal itu terlihat saat pembelajaran mewarnai, anak masih kurang mampu dalam mengenal warna sehingga pada saat mewarnai ada beberapa anak yang hanya menggunakan satu warna untuk mewarnai satu gambar.

Adanya kendala dalam pengembangan kreativitas mewarnai pada anak, maka pada tahap awal diperlukan kegiatan pengenalan konsep warna primer. Dari warna-warna yang terang kita dapat mengetahui kondisi emosi anak, kegembiraan dan kondisikondisi emosi mereka. Mengenal konsep pencampuran warna primer, sehingga 
menjadi warna yang sekunder dan tersier.

Upaya pengembangan kemampuan kreativitas mewarnai pada anak dilakukan melalui kegiatan Finger Painting dapat mengenalkan konsep pencampuran warna sehingga anak dapat mengembangkan kreativitas mewarnai.

Rumusan masalah yang ditetapkan dalam penelitian ini adalah: apakah kegiatan Finger Painting berpengaruh terhadap kemampuan kreativitas mewarnai pada peserta didik kelompok B TK Al-Hikmah Surabaya? Sedangkan hipotesis kerja yang diajukan adalah kegiatan finger Painting berpengaruh pada kemampuan kreativitas mewarnai pada peserta didik kelompok B TK AlHikmah Surabaya.

\section{METODE PENELITIAN}

Penelitian ini pendekatan penelitian kuantitatif dengan desain Pre-Eksperimental One Grup Pretest-Posttest Design (Arikunto, 2013:349, Sugiono, 2018). Rancangan penelitiannya sebagai berikut.

\section{$\mathrm{O}_{1} \times \mathrm{O}_{2}$}

Keterangan:

$\mathrm{O}_{1}$ adalah nilai pretest (sebelum diberi perlakuan/treatment)

$\mathrm{X}$ adalah perlakuan/treatment kegiatan finger painting

$\mathrm{O}_{2}$ adalah nilai post-test (setelah diberi perlakuan/treatment)
$\mathrm{O}_{2}-\mathrm{O}_{1}$ adalah selisih antara nilai posttest dengan pre-test yang merupakan pengeruh kegiatan finger painting terhadap kemampuan kreativitas mewarnai peserta didik

Teknik sampling yang diterapkan adalah Nonprobability sampling dengan bentuk sampling jenuh. Mangacu pada Sugiyono (2018:85) sampling jenuh adalah teknik penentuan sampel bila semua anggota populasi digunakan sebagai sampel. Teknik ini dilakukan karena jumlah populasi kurang dari 30 peserta didik. Istilah lain dari sampel jenuh adalah sensus, di mana semua anggota populasi dijadikan sampel. Jadi sampel yang diteliti pada penelitian ini adalah seluruh anak kelompok B TK AlHikmah Surabaya yang sebanyak 19 peserta didik.

Pengumpulan data menggunakan instrumen lembar observasi kinerja yang digunakan untuk mengamati kinerja (unjuk kerja) peserta didik baik pada saat pre-test, proses kegiatan maupun post-test. Observasi dilakukan berdasarkan rubrik observasi dan 3 (tiga) indikator yang sudah ditetapkan. Ketiga indikator tersebut adalah: a) mengenal konsep warna primer (merah, kuning, biru); $\quad$ b) mengenal konsep pencampuran warna primer menjadi warna sekunder dan tersier; c) imajinasi dan kreativitas anak. Sedangkan untuk menganalisis data dan menguji hipotesis digunakan uji statistik sesuai dengan 
rancangan penelitian. Teknik analisis

2.75

0.42

data yang diterapkan adalah uji $t$.

2.33

2.58

0.33

Hasil Penelitian

2.25

3.00

0.50

Data dari hasil penelitian ini dapat

2.50

2.46

0.50

dideskripsikan sebagai berikut.

1.96

1.92

2.46

0.54

1. Perbedaan rerata nilai pre tes masing-

2.04

2.54

0.50

masing peserta didik dapat digambarkan

1.92

2.50

0.58

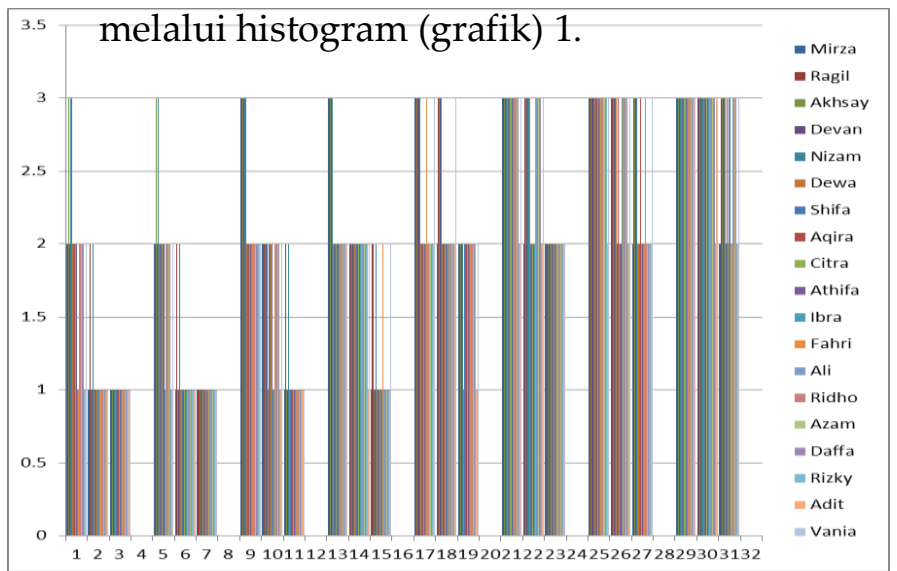

Grafik 1. Rerata Nilai Pre Test

2. Perbedaan rerata nilai pre tes masingmasing peserta didik dapat digambarkan melalui histogram (grafik) 2

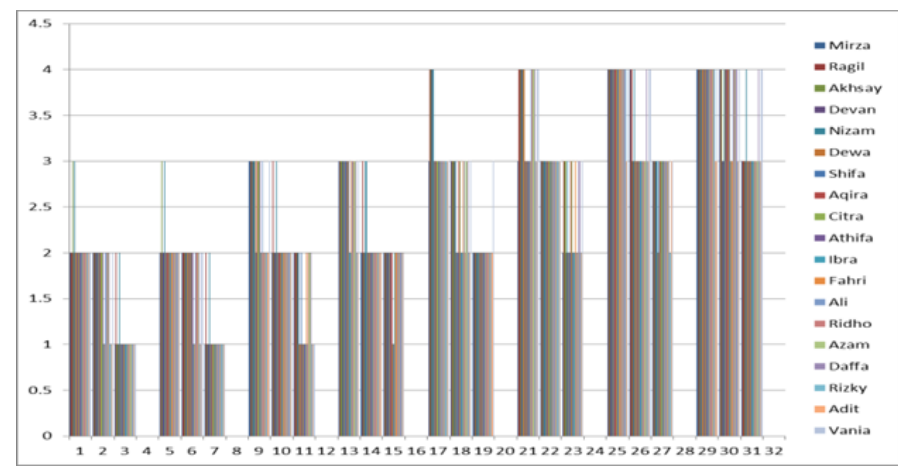

Grafik 2. Rerata Nilai Post Test

3. Perbedaan nilai pos-test dengan pretest sebagai dampak dari kegiatan finger painting dapat digambarkan seperti pada tabel berikut.

Tabel 1.Perbedaan hasil Pre test-Post test

$\begin{array}{cccc}\text { Subyek } & \text { Pre-Test } & \text { Post-Test } & \text { Gain } \\ 1 & 2.08 & 2.58 & 0.50 \\ 2 & 2.42 & 2.88 & 0.46\end{array}$

Rerata $=2.05 \quad$ Rerata $=2.39 \quad \mathrm{Md}=0,481$ Tabel 2 Persiapan T-test (uji t)

$\begin{array}{cccc}\text { Subyek } & \mathbf{d} & \mathbf{X}_{\mathbf{d}(\mathbf{d}-\mathbf{M d})} & \mathbf{X}_{\mathbf{d}}^{2} \\ 1 & 0.50 & -0.01 & 0.21 \\ 2 & 0.46 & 0.01 & 0.25 \\ 3 & 0.42 & 0.03 & 0.30 \\ 4 & 0.33 & 0.09 & 0.39 \\ 5 & 0.50 & -0.01 & 0.21 \\ 6 & 0.50 & -0.01 & 0.21 \\ 7 & 0.54 & -0.03 & 0.18 \\ 8 & 0.50 & -0.01 & 0.21 \\ 9 & 0.58 & -0.04 & 0.14 \\ 10 & 0.46 & 0.01 & 0.25 \\ 11 & 0.38 & 0.06 & 0.34 \\ 12 & 0.38 & 0.06 & 0.34 \\ 13 & 0.46 & 0.01 & 0.25\end{array}$




$\begin{array}{cccc}14 & 0.46 & 0.01 & 0.25 \\ 15 & 0.50 & -0.01 & 0.21 \\ 16 & 0.63 & -0.05 & 0.11 \\ 17 & 0.50 & -0.01 & 0.21 \\ 18 & 0.54 & -0.03 & 0.18 \\ 19 & 0.50 & -0.01 & 0.21 \\ \mathrm{~N}=19 & 9.13 & 4.47 & \sum \mathbf{x}_{\mathbf{d}}^{2}=4.47\end{array}$

Dari tabel 2 tersebut dilakukan perhitungan uji t sebagai berikut.

$$
\begin{aligned}
& =\frac{9,13}{19} \\
& =0,48 \\
& \sum x^{2} d=4,47 \\
& N=19 \\
& N-1=18 \\
& N(N-1)=19(18)=342 \\
& \sqrt{\frac{\sum x 2 d}{N[N-1)}}=0.11438 \\
& t_{\text {hit }}=\frac{0,480}{0.114} \\
& t_{\text {hit }}=4.20
\end{aligned}
$$

\begin{tabular}{|c|c|c|c|c|}
\hline Kegiatan & 0,05 & 4,20 & 1.734 & ditola \\
\hline $\begin{array}{l}\text { finger } \\
\text { painting }\end{array}$ & 0,01 & & 2.552 & $\mathrm{k}$ \\
\hline berpengaruh & & & & \\
\hline terhadap & & & & \\
\hline kemampuan & & & & \\
\hline kreativitas & & & & \\
\hline mewarnai & & & & \\
\hline
\end{tabular}

Secara ringkas hasil uji hipotesis tergambar seperti pada tabel 3 berikut.

Tabel 3. Ringkasan hasil analisis uji hipotesis

Hipotesis $\left(\mathrm{H}_{1}\right) \quad$ Signifikansi thitun tabel $\mathrm{H}_{0}$

\section{PEMBAHASAN}

Rumusan masalah yang sudah ditetapkan dalam penelitian ini adalah: apakah kegiatan Finger Painting berpengaruh terhadap kemampuan kreativitas mewarnai pada peserta didik kelompok B TK Al-Hikmah Surabaya?
Sedangkan hipotesis kerja yang diajukan adalah kegiatan finger Painting berpengaruh pada kemampuan kreativitas mewarnai pada peserta didik kelompok B TK Al-Hikmah Surabaya.

Tabel 3 di atas menunjukkan bahwa nilai $\mathrm{t}$ tabel lebih kecil daripada nilai $\mathrm{t}$ hitung baik pada taraf signifikansi 0,05 maupun pada taraf signifikansi 0,01. Dengan demikian Hipotesis Nol ditolak sehingga Hipotesis Kerja diterima. Dari tabel tersebut juga dapat diketahui bahwa nilai t-hitung jauh lebih besar daripada nilai t-tabel pada kedua taraf signifikansi itu, maka dapat dikatakan bahwa Hipotesis Kerja terbukti dengan signifikan. Dengan demikian dapat dikatakan juga bahwa kegiatan finger Painting berpengaruh pada kemampuan kreativitas mewarnai pada peserta didik kelompok B TK Al-Hikmah Surabaya.

Deskripsi hasil penelitian secara dikeseluruhan berdasarkan indikator variabel penelitian. Pembahasan ini dimaksud untuk mencegah terjadinya salah satu pengertian terhadap hasil analisis data serta untuk menambah kejelasan dalam menelaah permasalahan. dari data yang terkumpul dan dari hasil perhitungan data dari setiap treatment dapat diketahui atau menunjukkan bahwa peningkatan kreativitas mewarnai setelah dilakukan perlakuan dengan kegiatan finger painting. Hal ini dibuktikan pada treatment 1 dari 19 anak pada hasil pretest indikator 1 (mengenal konsep warna 
primer) yang belum berkembang 4 anak, yang mulai berkembang 13 anak dan yang berkembang sesuai harapan 2 anak. Pada indikator 2 (mengenal konsep pencampuran warna primer menjadi warna sekunder) yang belum berkembang 17 anak dan yang mulai berkembang 2 anak. Pada indikator 3 (melatih imajinasi dan kreativitas anak) yang belum berkembang 19 anak. Sedangkan hasil post-test indikator 1 (mengenal konsep warna primer) yang mulai berkembang ada 17 anak dan yang berkembang sesuai harapan ada 2 anak. Pada indikator 2 (mengenal konsep pencampuran warna primer menjadi warna sekunder) yang belum berkembang ada 4 anak dan yang mulai berkembang ada 15 anak. Pada indikator 3 (melatih imajinasi dan kreativitas anak) yang belum berkmebang ada 17 anak dan yang mulai berkembang ada 2 anak. Dengan demikian pada treatment 1 dapat dikatakan adanya peningkatan setelah perlakuan.

Pada treatment 2 dari 19 anak pada hasil pre-test indikator 1 (mengenal konsep warna primer) yang belum berkembang ada 3 anak, yang mulai berkembang ada 14 anak dan yang berkembang sesuai harapan ada 2 anak. Pada indikator 2 (mengenal konsep pencampuran warna primer menjadi warna sekunder) yang belum berkembang ada 17 anak dan yang mulai berkembang ada 2 anak. Pada indikator 3 (melatih imajinasi dan kreativitas anak) yang belum berkembang ada 19 anak. Sedangkan hasil post-test indikator 1 (mengenal konsep warna primer) yang mulai berkembang ada 17 anak dan yang berkembang sesuai harapan ada 2 anak. Pada indikator 2 (mengenal konsep pencampuran warna primer menjadi warna sekunder) yang belum berkembang ada 4 anak dan yang mulai berkembang ada 15 anak. Pada indikator 3 (melatih imajinasi dan kreativitas anak) yang belum berkembang ada 17 anak dan yang mulai berkembang ada 2 anak. Dengan demikian pada treatment 2 dapat dikatakan adanya peningkatan setelah perlakuan.

Pada treatment 3 dari 19 anak pada hasil pre-test indikator 1 (mengenal konsep warna primer) yang mulai berkembang ada 14 anak dan yang berkembang sesuai harapan ada 5 anak. Pada indikator 2 (mengenal konsep pencampuran warna primer menjadi warna sekunder) yang belum berkembang ada 4 anak dan yang mulai berkembang ada 15 anak. Pada indikator 3 (melatih imajinasi dan kreativitas anak) yang belum berkembang ada 17 anak dan yang mulai berkmebang ada 2 anak. Sedangkan hasil post-test indikator 1 (mengenal konsep warna primer) yang mulai berkembang ada 8 anak dan yang berkembang sesuai harapan ada 11 anak. Pada indikator 2 (mengenal konsep pencampuran warna primer menjadi warna sekunder) yang mulai 
berkembang ada 17 anak dan yang berkembang sesuai harapan ada 2 anak. Pada indikator 3 (melatih imajinasi dan kreativitas anak) yang belum berkembang ada 9 anak dan yang mulai berkembang ada 10 anak. Dengan demikian pada treatment 3 dapat dikatakan adanya peningkatan setelah perlakuan.

Pada treatment 4 dari 19 anak pada hasil pre-test indikator 1 (mengenal konsep warna primer) yang mulai berkembang ada 14 anak dan yang berkembang sesuai harapan ada 5 anak. Pada indikator 2 (mengenal konsep pencampuran warna primer menjadi warna sekunder) yang mulai berkembang ada 19 anak. Pada indikator 3 (melatih imajinasi dan kreativitas anak) yang belum berkembang ada 15 anak dan yang mulai berkembang ada 4 anak. Sedangkan hasil post-test indikator 1 (mengenal konsep warna primer) yang mulai berkembang ada 3 anak dan yang berkembang sesuai harapan ada 16 anak. Pada indikator 2 (mengenal konsep pencampuran warna primer menjadi warna sekunder) yang mulai berkembang ada 17 anak dan yang berkembang sesuai harapan ada 2 anak. Pada indikator 3 (melatih imajinasi dan kreativitas anak) yang belum berkembang ada 2 anak dan yang mulai berkembang ada 17 anak. Dengan demikian pada treatment 4 dapat dikatakan adanya peningkatan setelah perlakuan.
Pada treatment 5 dari 19 anak pada hasil pre-test indikator 1 (mengenal konsep warna primer) yang mulai berkembang ada 12 anak dan yang berkembang sesuai harapan ada 7 anak. Pada indikator 2 (mengenal konsep pencampuran warna primer menjadi warna sekunder) yang mulai berkembang ada 14 anak dan yang berkembang sesuai harapan ada 5 anak. Pada indikator 3 (melatih imajinasi dan kreativitas anak) yang belum berkembang ada 2 anak dan yang mulai berkembang ada 17 anak. Sedangkan hasil post-test indikator 1 (mengenal konsep warna primer) yang berkembang sesuai harapan ada 15 anak dan yang berkembang sangat baik ada 4 anak. Pada indikator 2 (mengenal konsep pencampuran warna primer menjadi warna sekunder) yang mulai berkembang ada 7 anak dan yang berkembang sesuai harapan ada 12 anak. Pada indikator 3 (melatih imajinasi dan kreativitas anak) yang mulai berkembang ada 18 anak dan yang berkembang sesuai harapan ada 1 anak. Dengan demikian pada treatment 5 dapat dikatakan adanya peningkatan setelah perlakuan.

Pada treatment 6 dari 19 anak pada hasil pre-test indikator 1 (mengenal konsep warna primer) yang mulai berkembang ada 2 anak, dan yang berkembang sesuai harapan ada 17 anak. Pada indikator 2 (mengenal konsep pencampuran warna primer menjadi 
warna sekunder) yang mulai berkembang ada 8 anak dan yang berkembang sesuai harapan ada 11 anak. Pada indikator 3 (melatih imajinasi dan kreativitas anak) yang mulai berkembang ada 19 anak. Sedangkan hasil post-test indikator 1 (mengenal konsep warna primer) yang berkembang sesuai harapan ada 9 anak dan yang berkembang sangat baik ada 10 anak. Pada indikator 2 (mengenal konsep pencampuran warna primer menjadi warna sekunder) yang berkembang sesuai harapan ada 19 anak. Pada indikator 3 (melatih imajinasi dan kreativitas anak) yang mulai berkembang ada 11 anak dan yang berkembang sesuai harapan ada 8 anak. Dengan demikian pada treatmentt 6 dapat dikatakan adanya peningkatan setelah perlakuan.

Pada treatment 7 dari 19 anak pada hasil pre-test indikator 1 (mengenal konsep warna primer) yang mulai berkembang ada 1 anak dan yang berkembang sesuai harapan ada 18 anak. Pada indikator 2 (mengenal konsep pencampuran warna primer menjadi warna sekunder) yang mulai berkembang ada 5 anak dan yang berkembang sesuai harapan ada 14 anak. Pada indikator 3 (melatih imajinasi dan kreativitas anak) yang mulai berkembang ada 12 anak dan yang berkembang sesuai harapan ada 7 anak. Sedangkan hasil post-test indikator 1 (mengenal konsep warna primer) yang berkembang sesuai harapan ada 1 anak dan yang berkembang sangat baik ada 18 anak. Pada indikator 2 (mengenal konsep pencampuran warna primer menjadi warna sekunder) yang berkembang sesuai harapan ada 14 anak dan yang berkembang sangat baik ada 5 anak. Pada indikator 3 (melatih imajinasi dan kreativitas anak) yang mulai berkembang ada 2 anak dan yang berkembang sesuai harapan ada 17 anak. Dengan demikian pada treatment 7 dapat dikatakan adanya peningkatan setelah perlakuan.

Pada treatment 8 dari 19 anak pada hasil pre-test indikator 1 (mengenal konsep warna primer) yang berkembang sesuai harapan ada 19 anak. Pada indikator 2 (mengenal konsep pencampuran warna primer menjadi warna sekunder) yang mulai berkembang ada 1 anak dan yang berkembang sesuai harapan ada 18 anak. Pada indikator 3 (melatih imajinasi dan kreativitas anak) yang mulai berkembang ada 6 anak dan yang berkembang sesuai harapan ada 13 anak. Sedangkan hasil post-test indikator 1 (mengenal konsep warna primer) yang berkembang sesuai harapan ada 1 anak dan yang berkembang sangat baik ada 18 anak. Pada indikator 2 (mengenal konsep pencampuran warna primer menjadi warna sekunder) yang berkembang sesuai harapan ada 5 anak dan yang berkembang sangat baik ada 14 anak. Pada indikator 3 (melatih 
imajinasi dan kreativitas anak) yang mulai berkembang sesuai harapan ada 16 anak dan yang berkembang sangat baik ada 3 anak. Dengan demikian pada treatmentt 8 dapat dikatakan adanya peningkatan setelah perlakuan.

Jika merujuk kepada hasil penelitian Kurnia (2015) tentang Pengaruh Kegiatan Painting dan Keterampilan Motorik Halus Terhadap Kreativitas Anak Usia Dini Dalam Seni Lukis Anak Kelompok B di TK Pertiwi Matanna Tikka Kecamatan Tanete Riattang Kabupaten Bone yang menunjukkan keterkaitan antara kegiatan painting dengan keterampilan motorik halus berpengaruh terhadap tinggi rendahnya hasil kreativitas anak usia dini dalam seni lukis. Cahyati, dkk meneliti tentang Penerapan Metode Pemberian Tugas Melalui Kegiatan Finger Painting Untuk Meningkatkan Kreativitas, hasilnya menunjukkan metode pemberian tugas melalui Finger Painting dapat meningkatkan kreativitas pada anak kelompok B 2 semester 2 tahun pelajaran 2014/2015 di RA Nurul Falah Patas. Hasil-hasil penelitian mengindikasikan adanya kesamaan dengan penelitian yang dilakukan oleh peneliti. Dari hasilhasil penelitian ini dapat dinyatakan bahwa kegiatan finger painting dapa mempengaruhi kemampuan kreativitas peserta didik usia dini.

\section{SIMPULAN}

Berdasarkan rumusan masalah dan hipotesis penelitian yang telah ditetapkan dan diperkuat dengan hasil analisis data yang menunjukkan bahwa nilai t-hitung=4.20 lebih besar daripada t-tabel=1.734 dengan taraf signifikansi 0.05 dan 2,552 pada taraf signifikansi 0,01 dengan $\mathrm{N}=19$ yang berarti hipotesis nihil $\left(\mathrm{H}_{\mathrm{o}}\right)$ ditolak dan hipotesis kerja $\left(\mathrm{H}_{\mathrm{l}}\right)$ diterima. Hal ini membuktikan bahwa hipotesis kerja $\left(\mathrm{H}_{\mathrm{l}}\right)$ yang menyatakan kegiatan finger painting berpengaruh terhadap kemampuan kreativitas mewarnai peserta didik kelompok B TK AlHikmah Kecamatan Rungkut Surabaya diterima. Dengan demikian dapat disimpulkan bahwa kegiatan finger painting berpengaruh secara signifikan terhadap kreativitas mewarnai peserta didik kelompok B TK Al-Hikmah Kecamatan Rungkut Surabaya.

\section{DAFTAR PUSTAKA}

Arikunto, Suharsimi. 2013. Prosedur Penelitian. Jakarta. Rineka Cipta.

Asrori, H. M. 2015. Perkembangan Peserta Didik. Yogyakarta. Media Akademi

Cahyati, Anis. Sulastri Made, Magta, Mutiara. 2015. Penerapan Metode Pemberian Tugas Melalui Kegiatan Finger Painting Untuk Meningkatkan Kreativitas.

Singaraja.Universitas Pendidikan Ganesha.

Kurnia, Dwi Selia. 2015. Pengaruh Kegiatan Painting dan Keterampilan 
Motorik Halus Terhadap Kreativitas Anak Usia Dini Dalam Seni Lukis. Jakarta. Universitas Negeri Jakarta.

Sugiyono. 2018. Metode Penelitian Kuantitatif, Kualitatif dan $R \& D$. Bandung. Alfabeta.

Sujiono, Yuliani Nurani. dan Sujiono Bambang. 2010. Bermain Kreatif Berbasis Kecerdasan Jamak. Jakarta. Indeks. 